\title{
HUMAN RIGHTS AND LABOR SOLIDARITY
}


PENNSYLVANIA STUDIES IN HUMAN RIGHTS

Series Editor: Bert B. Lockwood, Jr.

A complete list of books in the series is available from the publisher. 


\title{
HUMAN RIGHTS \\ AND LABOR SOLIDARITY
}

TRADE UNIONS

IN THE GLOBAL ECONOMY

\section{SUSAN L. KANG}

\author{
$\overline{\text { PENN }}$ \\ UNIVERSITY OF PENNSYLVANIA PRESS \\ PHILADELPHIA
}


Copyright (c) 2012 University of Pennsylvania Press

All rights reserved. Except for brief quotations used for purposes of review or scholarly citation, none of this book may be reproduced in any form by any means without written permission from the publisher.

\author{
Published by \\ University of Pennsylvania Press \\ Philadelphia, Pennsylvania 19104-4112 \\ www.upenn.edu/pennpress \\ Printed in the United States of America \\ on acid-free paper
}

$\begin{array}{llllllllll}2 & 4 & 6 & 8 & 10 & 9 & 7 & 5 & 3 & 1\end{array}$

\title{
Library of Congress Cataloging-in-Publication Data
}

Kang, Susan L.

Human rights and labor solidarity: trade unions in the global economy / Susan L. Kang. - 1st ed.

p. cm. - (Pennsylvania studies in human rights) Includes bibliographical references and index.

ISBN 978-0-8122-4410-6 (hardcover : alk. paper)

1. Labor unions. 2. Labor unions-Law and legislation.

3. Employee rights. 4. Human rights. I. Title. II. Series:

Pennsylvania studies in human rights.

HD6476.K36 2012

$331.88-\mathrm{dc} 23$ 
For my parents,

Young Chan Kang and Keesun Kang 
